Approval was given to the appointment of Dr P. T. W. Baxter of Manchester University as Associate Editor of Africa for a period of one year while the Editor, Professor J. D. Y. Peel, is on leave at the University of Chicago. Dr Murray Last, of University College, London, was likewise appointed Associate Reviews Editor for a period of one year during the absence abroad of the Reviews Editor, Dr Paul Richards, at the Njala College of the University of Sierra Leone.

It was decided to accept the kind invitation of the University of Zimbabwe to hold the next meeting of Executive Council at Harare, 5-9 July 1983.

\title{
Papers of the late Dr Derrick F. Stenning
}

Dr J. H. M. Beatie writes:

Readers of Africa may like to know that a substantial body of unpublished material by Dr Stenning, deriving from his researches in the former Ankole kingdom of western Uganda during the late 1950 s, is available for consultation. Despite the lapse of time, much of this material is still potentially of considerable importance and interest for students of the area and its people; it is likely that had he lived $\mathrm{Dr}$ Stenning would himself have gone on to publish at least a part of it.

Some years ago these materials were read, classified and re-filed by myself, following as far as possible Dr Stenning's original method of arrangement, and a detailed inventory of the contents of the thirty or so files involved, together with an assessment of the relative importance of the various items, was prepared. The material falls roughly into four main categories, of which the third and fourth, recording two detailed and intensive surveys carried out in two representative areas of Ankole, are of special interest.

The detailed and annotated inventory referred to, together with the material itself, can be consulted in the Manuscripts Room of Cambridge University Library. Would-be users should apply in advance to the Head of the Manuscripts Department.

\section{Second International Congress of Somali Studies}

The Congress is sponsored by the Somali Studies International Association and is due to take place at the University of Hamburg, 1-6 August 1983. Papers are invited in all areas of the social sciences, humanities and natural sciences. Papers may be submitted in any language, but an English translation must be provided to be considered for publication in the Congress proceedings. An exhibition of archival materials, manuscripts, books, and cultural items, as well as a programme of 'Somali' films and cultural events, is being planned. Further details from the Congress co-ordinators: Dr Thomas Labahn, Hagentwiete 31, 2083 Halstenbek, West Germany; Dr Hussein M. Adam, SSIA Secretariat, P.O. Box 2962, Moyadishu, Somalia.

\section{Suite de p. 86}

y sont ensuite décrites. Au cours des décades du milieu de ce siècle la possession Nyavingi qui auparavant était un culte officiel controlé par les chefs et consacré à assurer la santé et la productivité de la société, s'est transformée en un culte décentralisé s'occupant des malheurs individuels, et officié par des gens ordinaires. Ceci est en rapport avec la déstabilisation de la Chef-archie durant l'époque coloniale, et avec les perceptions des Bashu quant à la signification de ce changement politique en terms des conditions nécessaires au maintien d'une utopie de santé. 